\title{
Human osteoclast formation and bone resorption by monocytes and synovial macrophages in rheumatoid arthritis
}

\author{
Y Fujikawa, A Sabokbar, S Neale, N A Athanasou
}

Nuffield Department of Orthopaedic Surgery, University of Oxford, Oxford, United Kingdom Y Fujikawa

A Sabokbar

Department of Orthopaedics and Trauma, University of Adelaide, Adelaide, Australia

S Neale

Department of Pathology, Nuffield Orthopaedic Centre, Oxford, United Kingdom

N A Athanasou

Correspondence to: Dr N A Athanasou, Department of Pathology, Nuffield Orthopaedic Centre, Oxford OX3 $7 \mathrm{LD}$.

Accepted for publication 12 August 1996

\begin{abstract}
Objective-To determine whether synovial macrophages and monocytes isolated from patients with rheumatoid arthritis patients are capable of differentiating into osteoclastic bone resorbing cells; and the cellular and humoral conditions required for this to occur.

Methods-Macrophages isolated from the synovium and monocytes from the peripheral blood of rheumatoid arthritis patients were cultured on bone slices and coverslips, in the presence and absence of UMR 106 rat osteoblast-like cells, 1,25-dihydroxy vitamin $\mathrm{D}_{3}\left(1,25(\mathrm{OH})_{2} \mathrm{D}_{3}\right)$ and macrophage colony stimulating factor (M-CSF), and assessed for cytochemical and functional evidence of osteoclast differentiation.
\end{abstract}

Results-Isolated calcitonin receptor (CTR), tartrate resistant acid phosphatase (TRAP), and vitronectin receptor (VNR) negative, CD11b and CD14 positive monocytes and macrophages differentiated into CTR, TRAP, and VNR positive multinucleated cells capable of extensive lacunar bone resorption when co-cultured for $14 \mathrm{~d}$ with UMR 106 cells in the presence $1,25(\mathrm{OH})_{2} \mathrm{D}_{3}$ and $\mathrm{M}-\mathrm{CSF}$.

Conclusions-Mononuclear phagocytes (monocytes and macrophages) from rheumatoid arthritis patients are capable of differentiating into multinucleated cells showing all the cytochemical and functional criteria of mature osteoclasts. Synovial macrophage-osteoclast differentiation may represent an important cellular mechanism in the bone destruction associated with rheumatoid arthritis.

(Ann Rheum Dis 1996;55:816-822)

Rheumatoid arthritis is a chronic inflammatory disease of unknown aetiology that results in progressive damage to joint tissues. There is extension of exuberant inflamed synovial tissue (pannus) over the articular surface, leading to its destruction. ${ }^{1}$ Rheumatoid pannus also extends into juxta-articular bone, producing marginal erosions and cyst-like areas of bone destruction. In the inflamed synovium from which pannus develops, there is marked thickening of the synovial intima, which is composed largely of lining cells of macrophage phenotype $e^{2-5}$; there is also a heavy subintimal chronic inflammatory cells infiltrate which includes numerous lymphocytes, plasma cells, and macrophages. ${ }^{367-9}$ Both intimal and subintimal synovial macrophages in rheumatoid arthritis are derived from the circulation, blood monocytes passing through the tall endothelium of postcapillary venules to enter the synovial tissues. ${ }^{10}$

Macrophages rather than $T$ cells have been found to predominate at the articular margins where there is bone and cartilage destruction. $^{1112}$ A significant correlation has been reported between the degree of joint erosion and the number of synovial macrophages. ${ }^{13} \mathrm{At}$ the site of marginal erosions, bone resorption, however, appears to be effected largely by recognisable osteoclasts. ${ }^{14}$ Various macrophage derived cytokines are known to enhance osteoclastic bone resorption indirectly (through osteoblast stimulation $)^{15}$ and several of these cytokines also promote the release of collagenase, elastase, plasminogen activator, and prostaglandins by resident cells of bone and joint, ${ }^{1617}$ factors which may play a role in bone destruction in rheumatoid arthritis. ${ }^{18}$

Several recent animal studies have shown that monocytes and macrophages (including those isolated from tumours and inflammatory lesions) are capable of differentiating into osteoclastic bone resorbing cells when co-cultured with bone derived stromal cells in the presence of 1,25-dihydroxyvitamin $\mathrm{D}_{3}$ $\left(1,25(\mathrm{OH})_{2} \mathrm{D}_{3}\right)^{19-22}$; the mononuclear and multinucleated cells formed in these cocultures show all the phenotypic characteristics of osteoclasts, including expression of tartrate resistant acid phosphatase (TRAP), calcitonin receptors (CTR), and most importantly, the functional ability to produce resorption lacunae in bone. In the context of an inflammatory disease such as rheumatoid arthritis, where there is a heavy macrophage infiltrate in synovial tissues, osteoclast differentiation by monocytes and macrophages could represent an important mechanism for the pathogenesis of bone destruction. In this study we have sought to determine whether this cellular mechanism of osteoclast formation and pathological bone resorption operates in rheumatoid arthritis. Peripheral blood monocytes and synovial macrophages from rheumatoid arthritis patients were co-cultured with osteoblastic cells in the presence and absence of humoral factors which are known to be important in mouse osteoclast formation, in order to determine the cellular and humoral conditions for mononuclear phagocyte-osteoclast differentiation in rheumatoid arthritis. ${ }^{23-25}$ 


\section{Methods}

Synovial tissue was obtained fresh from six patients with seropositive rheumatoid arthritis, ${ }^{26}$ all of whom were undergoing knee arthroplasty operations. The synovial samples were obtained from five women and one man (age range 51 to 82 years).

Monocytes were isolated from the peripheral blood of eight patients with seropositive rheumatoid arthritis; seven women and one man were studied (age range 46 to 74 years).

ISOLATION AND CULTURE OF MONOCYTES AND SYNOVIAL MACROPHAGES

For isolation of monocytes, blood was diluted $1: 1$ in Hanks's balanced salt solution (HBSS) (Gibco, UK), layered over Ficoll Hypaque (Pharmacia), centrifuged, washed, and then resuspended in $5 \mathrm{ml}$ of $\alpha$ minimal essential medium (MEM) (Gibco, UK) with $10 \%$ fetal calf serum (Gibco, UK) containing glutamine, benzylpenicillin, and streptomycin (MEM) FCS). The number of cells in the resultant suspension was counted in a haemocytometer. Peripheral blood mononuclear cells $\left(5 \times 10^{5}\right.$ were then added to $7 \mathrm{~mm}$ diameter wells of 96-well plates containing human cortical bone slices $\left(5 \mathrm{~mm}^{2}\right)$, prepared as previously described, ${ }^{27}$ or $6 \mathrm{~mm}$ diameter glass coverslips, on half of which $4 \times 10^{4}$ osteoblast-like UMR 106 cells-a rat osteosarcoma cell line $\mathrm{e}^{28}$ - had previously been cultured for $24 \mathrm{~h}$ in MEM/FCS.

Specimen radiography was carried out on all samples of rheumatoid arthritis synovium to determine whether any bone particles were present in the synovial membrane; blocks were also taken for routine histology. The remainder of the synovial specimen was then cut into small pieces (approximately $1 \mathrm{~mm}^{3}$ ) and washed thoroughly in HBSS. The synovial fragments were digested in HBSS containing 1 $\mathrm{mg} \mathrm{ml}^{-1}$ collagenase type I (Sigma, UK) and $0.25 \%$ trypsin for $90 \mathrm{~min}$ at $37^{\circ} \mathrm{C}$. The suspension was filtered through a $70 \mu \mathrm{m}$ cell strainer (Falcon, UK) before being centrifuged at $680 \mathrm{~g}$ for $10 \mathrm{~min}$. The cell pellet was resuspended in $5 \mathrm{ml}$ MEM/FCS and the cell suspension $\left(1 \times 10^{5}\right.$ cells/well $)$ was then added

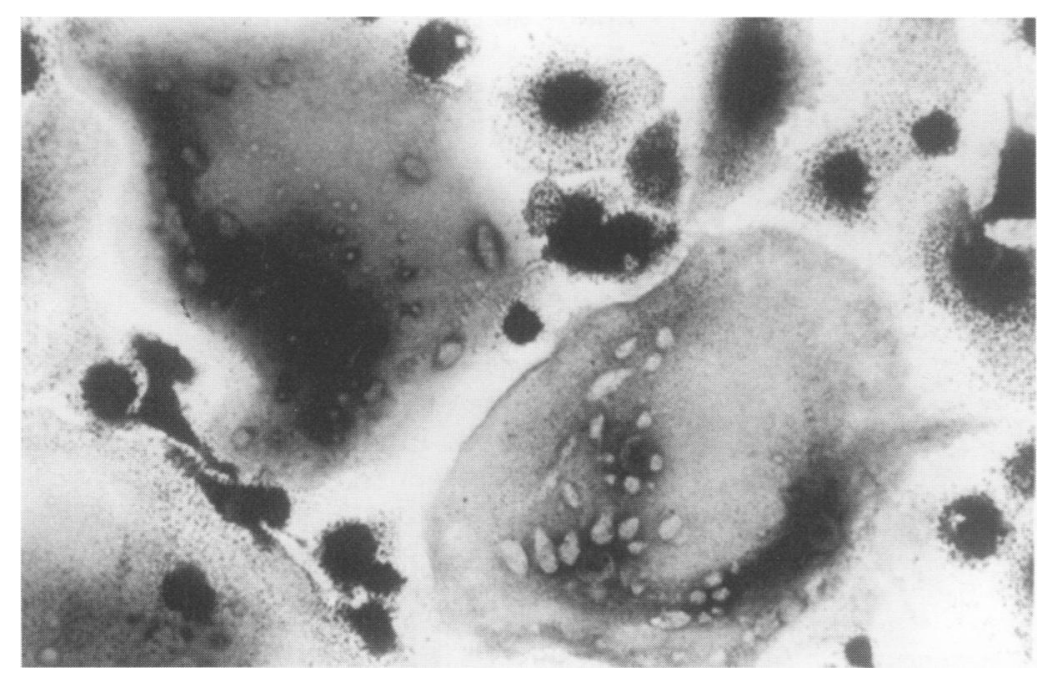

Figure 1 Rheumatoid synovial macrophage/UMR 106 co-culture after 14 d incubation, showing multinucleated cells positive for TRAP ( $\times 200)$. to bone slices and to glass coverslips, half of which had been preseeded with UMR 106 cells as described above.

The monocyte-UMR 106 and macrophageUMR 106 co-cultures were maintained in 24-well plates, in $1 \mathrm{ml} \mathrm{MEM/FCS} \mathrm{for} \mathrm{up} \mathrm{to} 14$ days, both in the presence and absence of $10^{-7}$ $\mathrm{M} 1,25(\mathrm{OH})_{2} \mathrm{D}_{3}$ (Solvay Duphar, The Netherlands), $25 \mathrm{ng} \mathrm{ml}^{-1}$ human macrophage colony stimulating factor (M-CSF) ( R \& D Systems, UK), and $10^{-8} \mathrm{M}$ dexamethasone. In all cultures, the medium (with added factors) was entirely replaced every 3 days.

As controls, cultures of monocytes and synovial macrophages were also set up with and without UMR 106 cells, and in the presence or absence of $1,25(\mathrm{OH})_{2} \mathrm{D}_{3}, \mathrm{M}-\mathrm{CSF}$, and dexamethasone.

\section{CYTOCHEMICAL AND IMMUNOCYTOCHEMICAL} CHARACTERISATION OF ISOLATED AND CULTURED CELLS

Isolated monocytes and macrophages which had been cultured on coverslips for 24 hours and 7 days were fixed in citrate acetone and stained for tartrate resistant acid phosphatase (TRAP), an osteoclast associated enzyme, ${ }^{29}$ using a kit from Sigma. For immunocytochemistry, cell cultures on coverslips were fixed in cold acetone and stained by an indirect immunoperoxidase technique ${ }^{30}$ for the detection of CD51, the vitronectin receptor (VNR), a highly osteoclast associated antigen, using monoclonal antibody 23C6 (a kind gift of Professor M Horton, London). ${ }^{31}$ Cultures on coverslips were also stained immunohistochemically for the presence of CD11b and CD14, monocyte/macrophage antigens known not to be expressed by human osteoclasts, ${ }^{31}$ with the monoclonal antibodies TMG6-5 and MEM-18 respectively. These monoclonal antibodies were derived from the 5 th International Workshop on Human Leucocyte Differentiation Antigens. ${ }^{33}$

DETECTION OF CALCITONIN RECEPTORS ON MONOCYTE CULTURES

Peripheral blood mononuclear cells isolated and cultured on glass coverslips in the presence and absence of UMR 106 cells, $1,25(\mathrm{OH})_{2} \mathrm{D}_{3}$, and M-CSF were assessed after incubation for 24 hours and 14 days for the presence of calcitonin receptors (CTR) by autoradiography using ${ }^{125}$ I-labelled salmon calcitonin ligand binding, as previously described. ${ }^{34}$ Briefly, peripheral blood mononuclear cells and UMR 106 cells were co-cultured on glass coverslips for one hour at $22^{\circ} \mathrm{C}$ in MEM/FCS containing $0.15 \%$ bovine serum albumin (BSA) with $0.25 \mu \mathrm{Ci}$ ${ }^{125}$ I-calcitonin (Amersham International, Aylesbury, UK). After allowing labelled calcitonin to bind for two hours, the cells were washed with cold MEM, fixed for 10 minutes in $2 \%$ glutaraldehyde- $10 \%$ formalin solution, and air dried. Non-specific binding was assessed in the presence of an excess amount of unlabelled calcitonin ( $300 \mathrm{nM}$ ). The coverslips were then dipped in $\mathrm{K}-5$ photographic emulsion and processed for autoradiography. Negative controls consisted of UMR 106 cells alone; positive controls consisted of adherent cultured rabbit osteoclasts. 


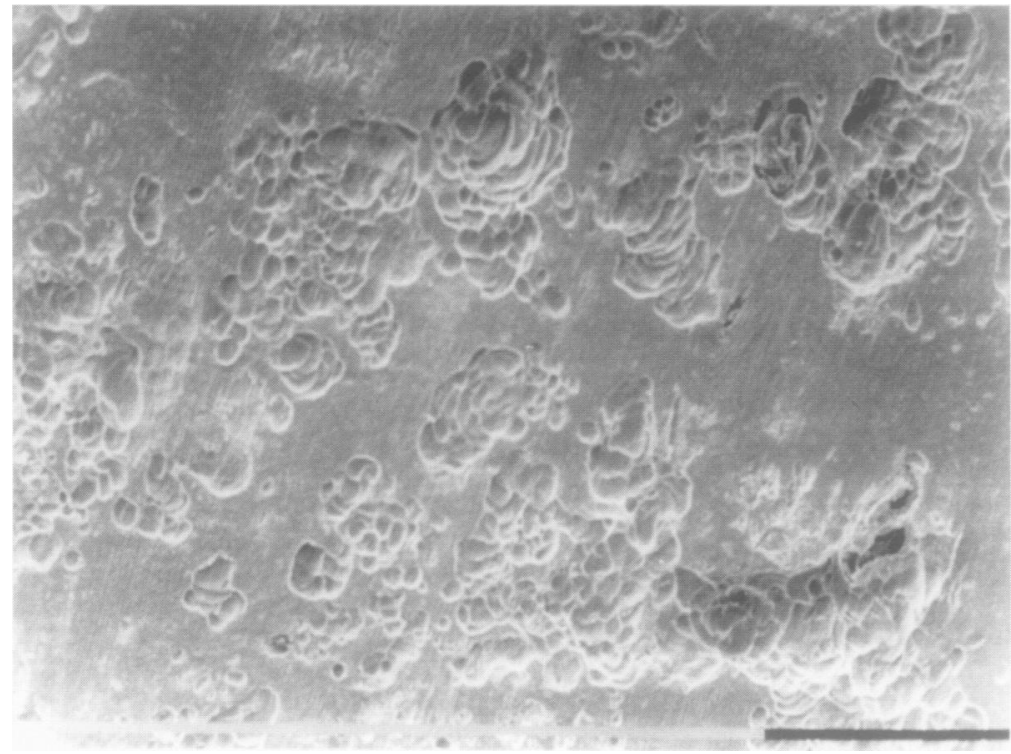

Figure 2 Lacunar resorption of human cortical bone slices seen in rheumatoid monocyte/UMR 106 co-cultures after 14 incubation (black bar $=100 \mu \mathrm{m}$ ).

FUNCTIONAL ASSESSMENT OF THE ABILITY OF CULTURED CELLS TO CARRY OUT LACUNAR BONE RESORPTION

Rheumatoid arthritis monocytes and macrophages incubated on bone slices in the presence and absence of UMR 106 cells and the humoral factors described above were cultured for periods of 24 hours, 7 days, and 14 days. To determine whether lacunar resorption of bone slices had occurred, confluent cell cultures were removed from the surface of the bone in the following manner: each bone slice was rinsed in phosphate buffered saline containing $0.2 \%$ EDTA, then placed in $0.25 \%$ trypsin solution for $10 \mathrm{~min}$, after which they were rinsed vigorously in distilled water and immersed in $0.25 \mathrm{M}$ ammonium hydroxide overnight; they were then washed in distilled water, dehydrated in graded alcohols, and air dried. The bone slices were mounted onto aluminium stubs using double sided Sellotape, sputtered with gold, and examined in a Phillips SEM 505 scanning electron microscope. The presence or absence of resorption pits on the

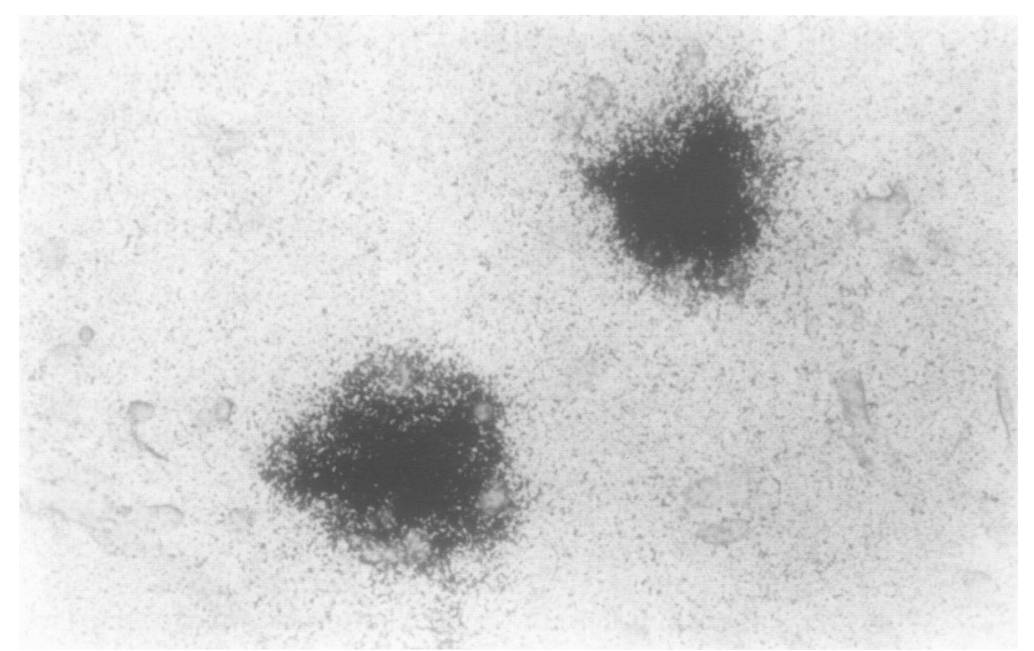

Figure 3 Rheumatoid monocyte/UMR 106 co-culture after $14 d$ showing the presence of calcitonin receptors on multinucleated cells by autoradiography using ${ }^{125}$ I labelled calcitonin (x 400). bone surface was noted, ${ }^{35}$ and the extent of resorption determined semiquantitatively.

\section{Results}

HISTOLOGY AND SPECIMEN RADIOGRAPHY OF RHEUMATOID ARTHRITIS SYNOVIAL SPECIMENS The specimens of rheumatoid synovium showed the typical histological features of this condition with villous thickening of the synovial membrane, intimal hyperplasia, and a heavy subintimal chronic inflammatory infiltrate, including numerous lymphocytes, plasma cells, and macrophages. On specimen radiography, it was noted that all rheumatoid synovial specimens contained small radioopaque fragments, and on histology these were found to represent small fragments of bone derived from the eroded joint; several of these bone fragments were surrounded by osteoclasts.

\section{CHARACTERISATION OF CELLS ISOLATED FROM} PERIPHERAL BLOOD AND SYNOVIUM IN $24 \mathrm{~h}$ CULTURES

Adherent cells isolated from the peripheral blood of rheumatoid arthritis patients were characterised as monocytes on the basis that, after being incubated alone on coverslips for 24 hours, they were entirely negative for osteoclast markers (that is, TRAP, VNR, and CTR ${ }^{293134}$; they strongly expressed CD11b and CD14 monocyte/macrophage antigens, which are known not to be expressed by osteoclasts. ${ }^{32}$ In addition, after 24 hours incubation on bone slices, no evidence of lacunar resorption was found on scanning electron microscopy. ${ }^{35} 36$ The above cytochemical, immunocytochemical, calcitonin receptor, and functional characteristics were seen when these isolated cells were cultured both in the presence or absence of UMR 106 cells, $1,25(\mathrm{OH})_{2} \mathrm{D}_{3}$, and M-CSF.

Cells isolated from the synovium of rheumatoid arthritis patients cultured for 24 hours on glass coverslips, both in the presence and absence of UMR 106 cells, $1,25(\mathrm{OH})_{2} \mathrm{D}_{3}$, and $\mathrm{M}-\mathrm{CSF}$, were also strongly CD11b and CD14 positive. Similarly, they were also entirely negative for the osteoclast markers, TRAP and VNR, and they did not produce lacunar resorption on bone slices.

\section{CYTOCHEMICAL AND IMMUNOPHENOTYPIC} CHARACTERISATION OF CELLS ISOLATED FROM PERIPHERAL BLOOD AND SYNOVIUM IN $7 \mathrm{~d}$ CULTURES

After seven days incubation on glass coverslips, co-cultures of rheumatoid arthritis monocytes and UMR 106 cells, in the presence of $1,25(\mathrm{OH})_{2} \mathrm{D}_{3}$ and $\mathrm{M}-\mathrm{CSF}$, contained numerous multinucleated cells which were positive for TRAP and VNR. In the absence of either UMR 106 cells, M-CSF, or $1,25(\mathrm{OH})_{2} \mathrm{D}_{3}$, only a few TRAP positive multinucleated cells and no VNR positive multinucleated cells were seen in some cultures. Scattered TRAP and VNR positive mononuclear cells were seen in all co-cultures after seven days incubation. Numerous CD11b and CD14 positive mononuclear cells and occasional multinucleated cells positive for these antigens were found 

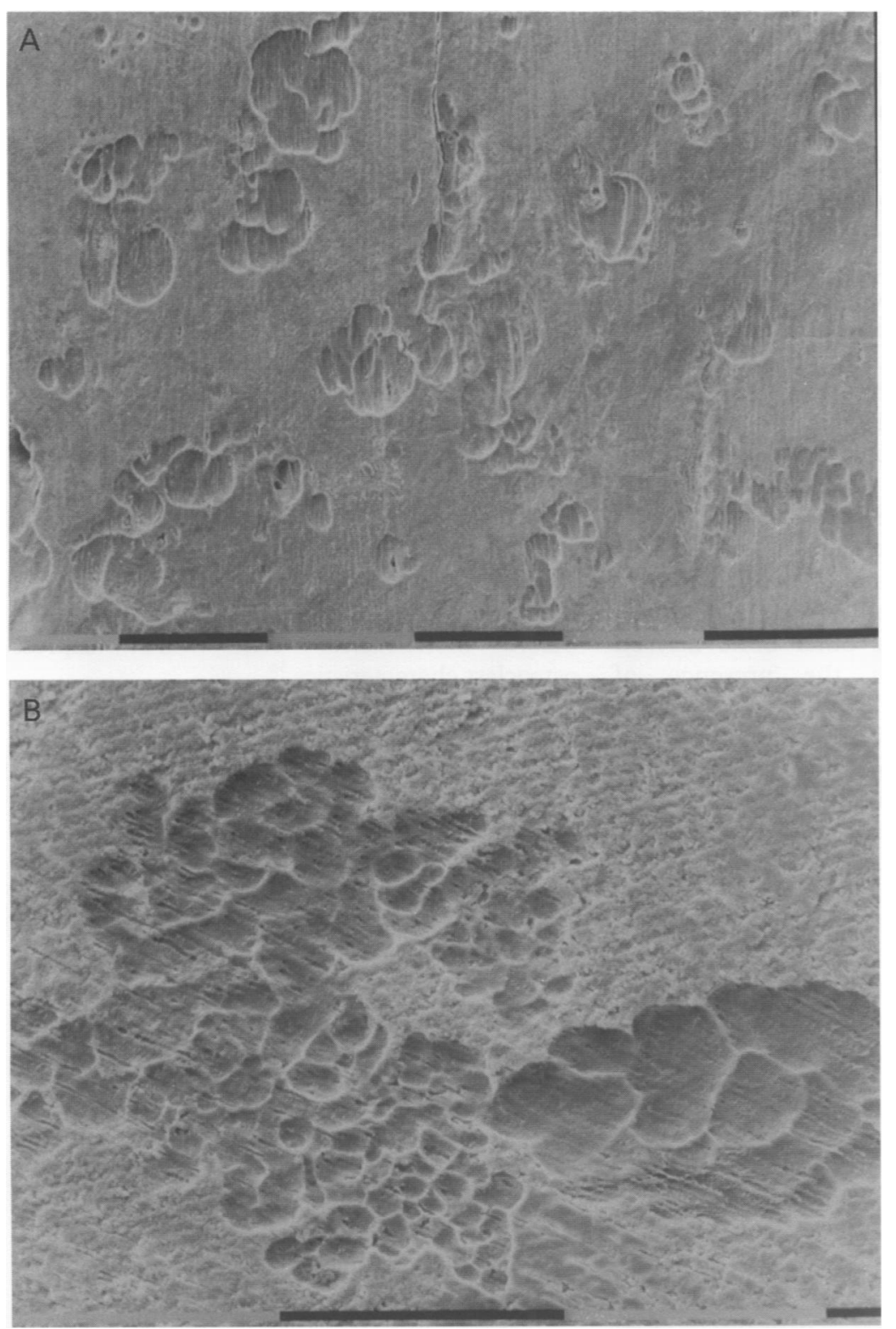

Figure 4 (A) Lacunar resorption pits on human cortical bone slice seen in rheumatoid synovial macrophage/UMR 106 co-culture after 14 dincubation (black bar $=100 \mu \mathrm{m}$ ).

(B) Higher power of one of the complex resorption pits (black bar $=100 \mu \mathrm{m}$ ).

in seven day cultures both in the presence and absence of UMR 106 cells.

Rheumatoid synovial macrophages cultured for seven days with UMR 106 cells, in the presence of $1,25(\mathrm{OH})_{2} \mathrm{D}_{3}$ and $\mathrm{M}-\mathrm{CSF}$, also contained numerous TRAP positive (fig 1 ) and VNR positive mononuclear and multinucleated cells. When incubated in the absence of UMR 106 cells, $1,25(\mathrm{OH})_{2} \mathrm{D}_{3}$ or $\mathrm{M}-\mathrm{CSF}$, all these cultures were found to contain mainly CD11b and CD14 positive mononuclear cells; however, cultures from two cases, incubated in the absence of the above factors, contained occasional TRAP and VNR positive multinucleated cells. However, scattered TRAP and VNR positive mononuclear cells were seen in all co-cultures after seven days incubation.

LACUNAR BONE RESORPTION AND CALCITONIN RECEPTOR EXPRESSION IN $14 \mathrm{~d}$ CO-CULTURES OF RHEUMATOID MONOCYTES AND MACROPHAGES WITH OSTEOBLAST-LIKE CELLS

After 14 days in culture, numerous resorption pits were seen on bone slices upon which rheumatoid monocytes had been co-cultured with
UMR 106 cells in the presence of $1,25(\mathrm{OH})_{2} \mathrm{D}_{3}, \mathrm{M}-\mathrm{CSF}$, and dexamethasone. Lacunar excavation was considerable, amounting to over 500 resorption pits (approximately $20 \%$ of the bone slice area), in some cases (fig $2)$. In all cases, over 50 resorption pits were seen on each bone slice when rheumatoid monocytes were cultured under these conditions. This extensive lacunar resorption was not seen when rheumatoid monocytes were cultured for 14 days in the absence of UMR 106 cells, or when $1,25(\mathrm{OH})_{2} \mathrm{D}_{3}$ or M-CSF was omitted from monocyte-UMR 106 co-cultures. Although dexamethasone was not an absolute requirement for lacunar bone resorption, its addition to rheumatoid monocyte-UMR 106 co-cultures (with added $1,25(\mathrm{OH})_{2} \mathrm{D}_{3}$ and $\left.\mathrm{M}-\mathrm{CSF}\right)$ considerably increased the extent of the lacunar resorption seen.

The presence of calcitonin receptors was also determined by autoradiography in 14 day monocyte cultures, where it was found that CTR positive multinucleated cells were present only in co-cultures of rheumatoid monocytes and UMR 106 cells which had been incubated in the presence of $1,25(\mathrm{OH})_{2} \mathrm{D}_{3}$ and M-CSF (fig 3). When monocytes were incubated alone on glass coverslips, or with UMR 106 cells alone, or with UMR 106 in the absence of $1,25(\mathrm{OH})_{2} \mathrm{D}_{3}$ or $\mathrm{M}-\mathrm{CSF}, \mathrm{CTR}$ positive cells were not seen.

Fourteen day co-cultures of rheumatoid arthritis synovial macrophages with UMR 106 cells, when incubated with $1,25(\mathrm{OH})_{2} \mathrm{D}_{3}$, $\mathrm{M}-\mathrm{CSF}$, and dexamethasone, also showed evidence of extensive lacunar resorption on all bone slices, over 200 resorption pits being noted in some cases (fig 4). In the absence of UMR 106 cells, 14 day rheumatoid arthritis macrophage cultures on bone slices, even when incubated in the presence of $1,25(\mathrm{OH})_{2} \mathrm{D}_{3}$ and $M-C S F$, showed no evidence of lacunar resorption. Lacunar resorption was also not seen in rheumatoid macrophage-UMR 106 co-cultures when $1,25(\mathrm{OH})_{2} \mathrm{D}_{3}$ or $\mathrm{M}-\mathrm{CSF}$ was omitted from the culture medium.

\section{Discussion}

This is the first report of human osteoclast formation and bone resorption by mononuclear phagocytes isolated from patients with rheumatoid arthritis. It indicates that mononuclear phagocytes, either present in the inflamed synovial membrane or recruited to the synovium from the circulation, may directly contribute to the osteolysis of rheumatoid arthritis by themselves differentiating into multinucleated cells which show all the cytochemical and functional features of osteoclasts. This study has also characterised the cellular and humoral conditions required for this to occur, showing that osteoblastic cells, $1,25(\mathrm{OH})_{2} \mathrm{D}_{3}$, and M-CSF are essential for osteoclast formation from rheumatoid monocytes and macrophages.

Cells isolated from the peripheral blood and synovial membrane were characterised as monocytes and macrophages on the basis that they did not express the osteoclast markers of 
TRAP, ${ }^{29}, \mathrm{VNR}_{,}{ }^{31}$, and $\mathrm{CTR},{ }^{34}$ and did not possess the ability to form resorption lacunae after 24 hours in culture, a functional feature which is characteristic of osteoclasts ${ }^{3536}$; these cells, however, did express CD11b and CD14 mononuclear phagocyte antigens which are known not to be expressed by osteoclasts. ${ }^{32}$ Although cells expressing these antigens persisted in all the long term monocyte/ macrophage-UMR 106 co-cultures examined, it was noted that multinucleated cells which expressed the above osteoclast phenotypic characteristics, including that of lacunar resorption, formed only when rheumatoid monocytes or macrophages were co-cultured with UMR 106 cells in the presence of $1,25(\mathrm{OH})_{2} \mathrm{D}_{3}$ and $\mathrm{M}$-CSF.

Previous studies have shown that mouse monocytes and macrophages are capable of osteoclast differentiation when co-cultured with UMR 106 cells or other bone derived stromal cell types in the presence of $1,25(\mathrm{OH})_{2} \mathrm{D}_{3}$ alone. ${ }^{192021-2237}$ The present study shows that the above factors are also essential for the in vitro formation of human osteoclasts from rheumatoid arthritis monocytes and macrophages, and that M-CSF is an additional essential cofactor. This requirement for human M-CSF is not surprising as it has previously been shown that rodent M-CSF (which would be secreted by UMR 106 cells) does not bind to the human M-CSF receptor (which would be present on the mononuclear phagocytes isolated from the circulation or synovium of rheumatoid arthritis patients). ${ }^{38}$ M-CSF is known to be necessary for the proliferation and differentiation of haematopoietic osteoclast progenitors, ${ }^{25} 39$ and an abnormality in the gene for M-CSF has been found to be the cause of the deficiency in osteoclast and bone macrophage numbers in osteopetrotic oplop mice. ${ }^{40-42}$ Synovial macrophages are themselves known to produce $1,25(\mathrm{OH})_{2} \mathrm{D}_{3}{ }^{43}$ and M-CSF is produced by both bone cells and cells found within the inflamed synovium. ${ }^{24} 44^{45-47}$ The synovial membrane is known to be a source of other cytokines and growth factors which influence osteoclast differentiation. ${ }^{48-51}$ One of these cytokines is interleukin (IL)-6, receptors for which have been shown to be induced on osteoblastic cells by dexamethasone $e^{24}$; this may explain the marked increase in bone resorption we observed when dexamethasone was added to monocyte/macrophage-UMR 106 co-cultures. IL-6 and soluble IL -6 receptors in the synovial fluid of rheumatoid patients have also recently been shown to be associated with the formation of osteoclast-like cells. ${ }^{51}$

Analysis of the immunophenotype of synovial lining cells and subintimal macrophages in the synovial membrane has shown that these cells strongly express monocyte/ macrophage markers such as HLA-DR, Fc, and $\mathrm{C}_{3}$ receptors, as well as a wide range of leucocyte/macrophage antigens, including $\mathrm{CD} 11 \mathrm{~b}$ and CD14. ${ }^{68}$ In rheumatoid arthritis, when the synovial intima becomes hyperplastic, over $90 \%$ of the synovial lining cells are commonly of macrophage phenotype, and there is an increase in macrophages in the subintima. ${ }^{9}$ Cellular kinetic and immunophenotypic studies have shown that synovial macrophages are derived from circulating monocytes which pass through tall endothelial cells of postcapillary venules before migrating to their tissue location in the intima or subintima. ${ }^{4510}$ These synovial macrophages differentially express certain activation markers which are associated with their ability to carry out a number of complex functions..$^{52}$ In rheumatoid arthritis, circulating monocytes themselves have been reported to show enhanced metabolic and phagocytic activity and to express surface markers consistent with macrophage activation. ${ }^{534}$ Monocytes are known to be chemotactically attracted to constituents of the bone matrix, ${ }^{55}$ and cytochemical and ultrastructural studies have shown that macrophage-like mononuclear cells appear at resorption surfaces before mononuclear cells which express osteoclast characteristics. $^{56}$

Synovial macrophages are believed to play a crucial role in joint destruction in rheumatoid arthritis. They are known to release numerous cytokines, principally $\mathrm{IL}-1$ and tumour necrosis factor $\alpha,{ }^{1516}$ which act on osteoblasts to stimulate osteoclastic bone resorption indirectly; in addition, they are known to release or to promote the release of prostaglandins and tissue proteases which may play a role in bone lysis. ${ }^{1416}{ }^{17}$ However, mature tissue macrophages, even in the presence of these factors, are incapable of causing lacunar resorption of a mineralised substrate. ${ }^{36}$ This is also the case for rheumatoid synovial macrophages, as confirmed in this study. ${ }^{57}$ However, our findings do indicate that synovial macrophages, like monocytes, are capable of altering their phenotype to that of osteoclasts when cultured under specific cellular and humoral conditions. In the same manner as osteoclast precursors derived from haematopoietic tissues, these mononuclear phagocytes acquire osteoclastic features and lose their macrophage phenotypic features respectively in the process of osteoclast differentiation. Monocyte-osteoclast and macrophageosteoclast differentiation does not appear to be particular to rheumatoid arthritis, as we have shown that in both man and experimental animals peripheral blood mononuclear cells and tissue macrophages are capable of osteoclast differentiation when cultured with osteoblastlike cells under similar culture conditions. ${ }^{20} 3759$

Monocytes and macrophages do not represent homogeneous cell populations but include a fraction of morphologically indistinguishable immature cells capable of further division..$^{60}$ In the context of bone resorption in rheumatoid arthritis, it is possible that these immature mononuclear phagocytes, either as monocytes recruited into the synovium or as synovial macrophages, are capable - when placed in the cellular and humoral microenvironment of bone (that is, when they come in contact with bone lined by osteoblasts in the presence of $1,25(\mathrm{OH})_{2} \mathrm{D}_{3}$ and $\mathrm{M}-\mathrm{CSF}$ - - of proliferation and differentiation into bone resorbing osteoclasts, the tissue 
specific mononuclear phagocyte of bone. The essential cellular and humoral conditions for human osteoclast formation from monocytes and macrophages are present in the in vitro co-culture system described in this study. It should provide a useful model for the analysis of the role that synovial macrophage-osteoclast differentiation plays in the bone destruction associated with rheumatoid arthritis and other arthritic diseases.

We would like to thank Mrs Margaret Pearce for typing the manuscript. This work was supported by the Nuffield Foundation (Oliver Bird Fund) and the Wellcome Trust.

1 Gardner DC. The pathology of rheumatoid arthritis. London: Edward Arnold, 1992.

2 Burmester GR, Loacher P, Winchester RJ, Dimitriu-Bona Kalden JR, Mohr W. The tissue architecture of synovial membranes in inflammatory and non inflammatory join diseases. Rheumatol Int 1983;3:173-81.

3 Hogg N, Palmer DG, Revell PA. Mononuclear phagocytes of normal and rheumatoid synovial membrane identified by monoclonal antibodies. Immunology 1985;56:673-81.

4 Athanasou NA, Quinn J, Heryet A, Puddle B, Woods CG, McGee JOD. The immunohistology of synovial lining cells in normal and inflamed synovium. F Pathol 1988;155:133 42.

5 Henderson B, Revell PA, Edwards JC. Synovial lining cel hyperplasia in theumatoid arthritis: dogma and fact. Ann Rheum Dis 1988;47:348-9.

6 Allen CA, Highton J, Palmer GD. Increased expression of P150, 95 and CR3 leukocyte adhesion molecules by mononuclear phagocytes in rheumatoid synovial membrane. Comparison with osteoarthritic and normal synovial membranes. Arthritis Rheum 1989;32:947-54.

7 Hale LP, Martin ME, McCollum DE, Nunley JA, Springer $\mathrm{TA}$, Singer $\mathrm{KH}$, et al. Immunohistologic analysis of the distribution of cell adhesion molecules within the inflam matory synovial microenvironment. Arthritis Rheum 1989, 32:22-30.

8 Broker BM, Edwards JCW, Fanger MW, Lydyard PM, The prevalence and the distribution of macrophage bearing FcRI, FcRII and FcRIII in synovium. Scand $\mathcal{f}$ Rheumato 1990;19:123-35.

9 Athanasou NA, Immunophenotypic analysis of mononuclear phagocyte antigens in the arthritic synovium of the hip joint. Hip Int 1993;3:67-74.

10 Ziff M. Pathways of mononuclear cell infiltration in rheumatoid synovitis. Rheumatol Int 1989;9:97-103.

11 Bromley M, Woolley DE. Histopathology of the rheumatoid lesion: identification of cell types at sites of cartilage erosion. Arthritis Rheum 1984;27:857-63.

12 Aclard SA, Bayliss MT, Maini RN. They synovium-cartilage junction of the normal human knee: implications for join destruction and repair. Arthritis Rheum 1990;33:1170-9.

13 Yanni G, Whelan A, Feighery C, Bresnihan B. Synovial tissue macrophages and joint erosion in rheumatoid arthritis. Ann Rheum Dis 1994;53:39-44.

14 Bromley M, Woolley D. Chondroclasts and osteoclasts at subchondral sites of erosion in the rheumatoid joint. Arthritis Rheum 1984;27:857-63.

15 Skerry $T$, Gowen $M$. Bone cells and bone remodelling in rheumatoid arthritis. In: Henderson B, Edwards JEW, Pettipher ER, eds. Mechanisms and models in rheumatoid arthritis. London: Academic Press, 1995:205-20.

16 Brennan FM, Field M, Chu CQ, Feldmann M, Maini RM Cytokine expression in rheumatoid arthritis. $\mathrm{Br} f$ Rheumatol 1991;30(suppl 1):76-80.

17 Zvaifler NJ, Firestein GS. Pannus and pannocytes: alternative models of joint destruction in rheumatoid arthritis. Arthritis Rheum 1994;37:783-9.

18 Dingle JT. The role of cellular interactions in joint erosions. Clin Orthop 1984;182:24-9.

19 Udagawa N, Takahashi N, Akatsu T, Tanaka H, Sasaki T, Nishihara T, et al. Origin of osteoclasts: mature monocytes and macrophages are capable of differentiating into osteoclasts under a suitable microenvironment prepared by
bone marrow-derived stromal cells. Proc Natl Acad Sci USA 1990;87:7260-4.

20 Quinn J, McGee JO D, Athanasou NA. Cellular and hormonal factors influencing monocyte differentiation to osteoclastic bone resorbing cells. Endocrinology 1994; 134:2416-23.

21 Quinn JM, Joyner C, Triffitt JT, Athanasou NA Polymethylmethacrylate-induced inflammatory macrophages resorb bone. $\mathcal{F}$ Bone foint Surg Br 1992;74B:652-8.

22 Quinn J, Athanasou NA. Tumour infiltrating macrophage are capable of bone resorption. $\mathcal{f}$ Cell Sci 1992;101:681-6.

23 Takahashi N, Yamana H, Yoshiki S, Roodman GD, Mundy GR, Jones SJ, et al. Osteoclast-like cell formation and its regulation by osteotropic hormones in mouse bone marrow cultures. Endocrinology 1988;122:1373-82.

24 Suda T, Udagawa N, Nakamura I, Miyaura C, Takahashi N. Modulation of osteoclast formation by local factors. Bon 1995;17(suppl 2):875-915.
25 Tanaka S, Takahashi N, Udagawa N, Tamura T, Akatsu T, Stanley ER, et al. Macrophage colony stimulating factor is indispensable for both proliferation and differentiation of osteoclast progenitors. $\mathcal{F}$ Clin Invest 1993;91:257-63.

26 Arnett C, Edworthy SM, Bloch DA, McShane DJ, Fries JF Cooper NS, et al. The American Rheumatism Association 1987 revised criteria for the classification of rheumatoid 1987 revised criteria for the classification
arthritis. Arthritis Rheum 1988;31:315-24.

27 Athanasou NA, Wells CA, Quinn J, Ferguson DP, Heryet A $\mathrm{McGee}$ JOD. The origin and nature of stromal osteoclastlike multinucleated giant cells in breast carcinoma: implications for tumour osteolysis and macrophage biology. $\mathrm{Br}$ $\mathfrak{f}$ Cancer 1989;59:491-498.

28 Partridge N, Alcorn D, Michelangeli V, Kemp E, Ryan G, Martin TJ. Functional properties of hormonal responsive cultured normal and malignant rat osteoblastic cells. Endocrinology 1981;108:213-9.

29 Andersson G, Ek-Rylander B, Minkin C. Acid phosphatases. In: Rifkin BR, Gay CV, eds. Biology and physiology of the osteoclast. Boca Raton: CRC Press, 1992:55- 80 .

30 Gatter KC, Falini B, Mason DY. 1984 The use of monoclonal antibodies in histological diagnosis. In Anthony PP, MacSween RNM, eds. Recent advances in histopathology, No 12. Edinburgh: Churchill Livingstone, 1984:35-67.

31 Horton MA, Lewis D, McNulty K, Pringle JAS, Chambers TJ. Monoclonal antibodies to osteoclastomas (giant cell bone tumours): definition of osteoclast specific cellular antigens. Cancer Res 1985;45:5663-9.

32 Athanasou NA, Quinn J. Immunophenotypic differences between osteoclasts and macrophage polykaryons: immunohistological distinction and implications for osteoclast ontogeny and function. $\mathcal{f}$ Clin Pathol 1990;43:997-1004.

33 Schlossman SF, Boumsell L, Gilks W, Harlan JM Kishimoto T, Morimoto C, et al. Leucocyte typing V: white cell differentiation antigens. Oxford: Oxford University Press, 1995.

34 Nicholson CG, Moseley JM, Sexton PM, Mendelsohn FAO. Abundant calcitonin receptors in isolated rat osteoclasts. $\mathcal{F}$ Clin Invest 1986;78:355-60.

35 Chambers TJ, Revell PA, Fuller K, Athanasou NA. Resorption of bone by isolated rabbit osteoclasts. F Cell Sci 1984; 66:383-99.

36 Chambers TJ, Horton MA. Failure of cells of the mononuclear phagocyte series to resorb bone. Calcif Tissue Int 1984;36:556-68.

37 Quinn JMW, Sabokbar A, Athanasou NA. Cells of the mononuclear phagocyte series differentiate into osteoclastic lacunar bone-resorbing cells. f Pathol 1996;179:106-11.

38 Roussel MF, Downing JR, Rettenmeier CW, Sherr CJ. A point mutation in the extra cellular domain of the human CSF-1 receptor (c-fms product) activates its transforming CSF-1 receptor (c-fms product)

39 Kodama H, Nose M, Niida S, Yamasah A. Essential role of macrophage-colony stimulating factor in the osteoclast differentiation supported by stromal cells. $f$ Exp Med 1991;173:1292-4.

40 Yoshida H, Hayashi S-I, Kunisada T, Ogawa M, Nishikawa $\mathrm{S}$, Okamura $\mathrm{H}$, et al. The murine mutation osteopetrosis is in the coding region of the macrophage colony stimulating factor gene. Nature 1990;345:442-4.

41 Felix R, Cecchini MG, Fleisch H. Macrophage colony stimulating factor restores in vivo bone resorption in the op/op osteopetrotic mouse. Endocrinology 1990;127:2592op/op

42 Felix R, Cecchini MG, Hofstetter W, Elford PR, Stutzer A Fleisch $\mathrm{H}$. Impairment of macrophage colony stimulating factor production and lack of resident bone marrow macrophages in the osteopetrotic op/op mouse. F Bone Miner Res 1990;5:781-9.

43 Hayes ME, Denton J, Freemont AJ, Mawer EB. Synthesis of the active metabolite of vitamin $\mathrm{D}, 1,25(\mathrm{OH})_{2} \mathrm{D}_{3}$, by synovial fluid macrophages in arthritic disease. Ann Rheum Dis 1989;48:723-9.

44 Shern CJ. Colony-stimulating factor-1 receptor. Blood 1990;75:1-12

45 Weir EC, Horowitz MC, Baron R, Centrolla M, Kacinski $\mathrm{BM}$, Insogna $\mathrm{KL}$. Macrophage-colony stimulating factor release and receptor expression in bone cells. $\mathcal{f}$ Bone Miner Res 1993;8:1507-18.

46 Smith JB, Borchieri MH, Smith JB, Sherbin-Allen L Abruzzo JL. Colony stimulating factor occurs in both inflammatory and non inflammatory synovial fluids. Rheumatol Int 1990;10:131-4.

47 Seitz M, Loestscher $P$, Fey MF, Tobler A Constitutive mRNA and protein production of macrophage-colony stimulating factor but not of other cytokines by synovial stimulating factor but not of other cytokines by synovial fibroblasts from rheumatoid arthritis a

48 Chin J, Rupp E, Cameron PM, MacNaul KL, Lotke PA Tocci MJ, et al. Identification of a high-affinity receptor for interleukin 1 and interleukin 1 on cultured human rheumatoid synovial cells. $\mathcal{f}$ Clin Invest 1988;82:420-6.

49 Xu WD, Firestein GS, Taetle R, Kaushansky K, Zvaifler NJ. Cytokines in chronic inflammatory arthritis II: granulocytemacrophage colony stimulating factor in rheumatoid synovia effusions. $\mathcal{F}$ Clin Invest 1989;83:876-82.

50 Guerne P-A, Zuraw BL, Vaughan JH, Carson DA, Lotz M. Synovium as a source of interleukin-6 in vitro. $\mathcal{f}$ Clin Invest 1989;83:585-92.

51 Kotake S, Sato K, Kim KJ, Takahashi N, Udagawa N, Nakamura I, et al. Interleukin-6 and soluble interleukin-6 receptors in the synovial fluids from rheumatoid arthritis 
patients are responsible for osteoclast-like cell formation. $\mathcal{f}$ Bone Miner Res 1996:11:88-95.

52 Adams DO, Hamilton TA. The cell biology of macrophage activation. Annu Rev Immunol 1984;2:283-318.

53 Fujii I, Shinju M, Noburaga M. Monocyte activation in early onset rheumatoid arthritis. Ann Rheum Dis 1990 early onset

54 McCarthy D, Taylor MJ, Bernhagen J, Perry JD, Hamblin AS. Leucocyte integrin and CRI expression on peripheral blood leucocytes of patients with rheumatoid arthritis. Ann Rheum Dis 1992;51:307-12.

55 Mundy GR, Varani J, Orr W, Gondek MD, Ward PA Resorbing bone is chemotactic for monocytes. Nature 1978;275:132-5.

56 Baron R, Tran Van P, Nefussi JR, Vignery A. Kinetic and cytochemical identification of osteoclast precursors and their differentiation into multinucleated osteoclasts. $A m \mathcal{F}$ Pathol 1986:122:363-78.

57 Chang JS, Quinn JMW, Demaziere A, Bulstrode CJ, Francis

$\mathrm{MJ}$, Duthie RB, et al. Bone resorption by cells isolated from the rheumatoid synovium. Ann Rheum Dis 1992; 51:1223-9.

58 Takahashi N, Udagawa N, Tanaka S, Murakanni H, Owan I, Tamura $T$, et al. Postmitotic osteoclast precursors are mononuclear cells which express macrophage-associated phenotypes. Dev Biol 1994;163:212-21.

59 Fujikawa Y, Quinn JMW, Sabokbar AS, McGee JO D, Athanasou NA. The human mononuclear osteoclast precursor circulates in the monocyte fraction. Endocrinology (in press)

60 van Furth $\mathrm{R}$. Origin and turnover of monocytes and macrophages. Curr Top Pathol 1989;79:125-50. 